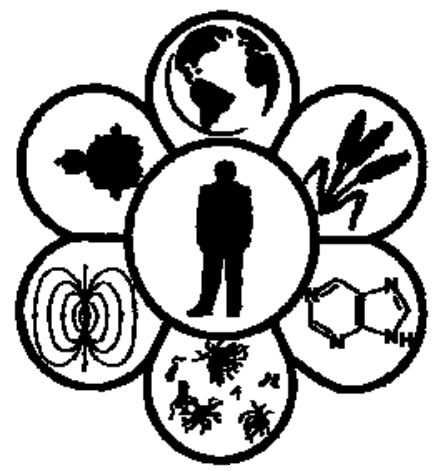

Вісник Дніпропетровського університету. Біологія, медицина Vìsnik Dnìpropetrovs'kogo unìversitetu. Seriâ Bìologiâ, medicina

Visnyk of Dnipropetrovsk University. Biology, medicine

Vìsn. Dnìpropetr. Unìv. Ser. Bìol. Med. 2014. 5(1), 62-65.

doi: $10.15421 / 021413$

ISSN 2310-4155 print

ISSN 2312-7295 online

www.medicine.dp.ua

УДК 577.156+612.015

\title{
Використання специфічних біомаркерів донних риб Керченської протоки для оцінки забруднення водних біоресурсів
}

\author{
О.В. Сухаренко \\ Керченський державний морський технологічний університет, Керч, Украӥна
}

\begin{abstract}
Сучасна екологічна ситуація у водах Керченської протоки потребує оцінки порушень у біотопах і моніторингу ступеня впливу промислових забруднень на екосистему. Відкладення нафтопродуктів після катастрофи судів у 2007 році може мати несприятливий вплив на стан біоценозів акваторії. Проведене дослідження цитоскелетного маркеру астроцитів гліального фібрилярного кислого білка (ГФКБ) у мозку бичка-пісочника (Neogobius fluviatilis), який є типовим представником промислових донних риб Керченського проливу. Результати порівняльного аналізу вмісту ГФКБ у мозку риб із прибережних вод бухти Керченська і 3 умовно чистої частини р. Ворскла показали достовірне збільшення ГФКБ (у 2,18 раза) у промислово забрудненому регіоні. Підвищення вмісту ГФКБ вказує на розвиток астрогліозу у результаті метаболічних порушень, які можуть бути викликані забрудненням нафтопродуктами придонних горизонтів бухти Керченська. У тканині мозку групи риб, виловлених у Керченській бухті виявлене збільшення вмісту продуктів перекисного окиснення ліпідів. Представлені результати порушень стану цитоскелету астроцитів $\mathrm{i}$ оксидативний стрес у мозку бичка-пісочника Керченської бухти свідчать про прояв сублетального біологічного ефекту промислових забруднювачів у гідробіонтів даної акваторії. Результати досліджень вказують на потребу постійного екологічного моніторингу та комплексного дослідження популяцій гідробіонтів промислових регіонів і зон екологічних катастроф.
\end{abstract}

Ключові слова: молекулярні маркери; гліальний фібрилярний кислий білок; промислове забруднення; водні біоресурси

\section{Assessment of Kerch Bay environmental pollution using neuroglial proteins of ground fish}

\author{
H.V. Sukharenko
}

\section{Kerch State Marine Technological University, Kerch, Ukraine}

The modern ecology situation in waters of the Kerch Strait requires assessment of disturbances in biotopes and monitoring of the degree of impact of industrial pollutants on ecosystem. Deposit of oil products after the 2007 year ships' accidents might have considerable impact on the water biocenosis area. The investigation of cytoskeleton marker of astrocytes glial fibrillary acidic protein (GFAP) in brain of the bullhead (Neogobius fluviatilis), which is the typical representative of the commercial ground fish of the Kerch Strait, has been carried out. The results of comparative analysis of GFAP content in the brain of fish from the Kerch Bay near-shore waters and fish from conditionally clear area of Vorskla river shows the reliable (2.18 times) increasing of GFAP in the area of industrial pollution. Rising GFAP content indicates the astrogliosis development as a result of metabolic disturbances which can be induced by higher content of oil products in the near-bottom biotopes of the Kerch Bay. Increase in lipid peroxidation level was observed in the brain of fish from the Kerch Bay. The results provided with regard to violations of the state of astrocyte cytoskeleton and oxidative stress in the brain of bullhead from the Kerch Bay prove the sublethal biology effect of industrial pollutants in hydrobionts from this area. Results of this investigation also indicate the necessity of continuous ecology monitoring and comprehensive study of hydrobiont populations in the industrial regions and ecological disaster zones.

Keywords: molecular markers; glial fibrillary acidic protein; industrial pollution; water bioresources

Керченський державний морський технологічний університет, вул. Орджсонікідзе, 82, Керч, 98309, АР Крим, Украӥна. Kerch State Sea Technology University, Ordjonikidze str., 82, Kerch, 98309, Cremia, Ukraine.

Tel.: +38-050-558-45-76.E-mail: helenasuhar@gmail.com 


\section{Вступ}

Відносне зниження промислових викидів за останні роки принципово не відбивається на екологічному стані водних біоресурсів України. Це зумовлено рядом об'єктивних причин. У деяких регіонах навіть зафіксовано значне погіршення показників тотального забруднення акваторій. Інтенсифікація судноплавства спричинила зростання ерозійних процесів і прогресуючої реседиментації донних відкладів. Збільшенню забруднення акваторії сприяла робота декількох морських портів і рейдовоперевантажувальних комплексів.

Представники зообентосу - основні об'єкти живлення донних промислових риб. Забруднення донних відкладів може спричинювати порушення екологічної рівноваги у популяціях донних риб. Саме тому надзвичайно актуальною є комплексна оцінка на всіх рівнях організації біологічних систем. Чутливим індикатором рівня комбінованої дії токсинів на рівновагу метаболічних процесів хребетних $є$ клітини нервової тканини. Найчутливішими до дії ушкоджувальних чинників клітинами нервової тканини є астроцити. Головним компонентом цитоскелета цих клітин $є$ гліальний фібрилярний кислий білок (ГФКБ), експресія якого є характерним показником реакції астроцитів у відповідь на ушкодження внаслідок дії несприятливих чинників різної природи (Nedzvetskii et al., 2006).

Мета дослідження - оцінити особливості астрогліозу, вмісту специфічного цитоскелетного маркера астроглії - гліального фібрилярного кислого білка (ГФКБ) в мозку бичка-пісочника (Neogobius fluviatilis), що $є$ типовим представником промислових донних риб Керченської протоки.

\section{Матеріал і методи досліджень}

Основою порівняльного аналізу були комплексні іхтіотоксикологічні, біохімічні та імунохімічні дослідження, збирання матеріалу та спостереження, проведені на акваторії річки Ворскла (Дніпродзержинське водосховище) у межах існуючого іхтіологічного заказника, що практично не потрапляє під техногенний вплив, i зони узбережжя бухти Керченської, в якій розташований ряд діючих портових комплексів. Іхтіологічний матеріал (38 екземплярів бичка-пісочника (N. fluviatilis) відбирали відповідно до загальноприйнятих методик у водах Керченської бухти у травні - червні 2012 р. Для порівняльного аналізу наведено також результати, отримані у 2012 р. щодо забрудненої ділянки р. Самара.

Вміст і склад поліпептидних фрагментів ГФКБ визначали імунохімічними методами. Фракціії розчинних та цитоскелетних білків мозку риб отримували як це описано раніше (Nedzvetskii et al., 2006). Визначення вмісту та поліпептидного складу гліальних філаментів проводили за допомогою імуноблотингу (Nedzvetskii et al., 2006). Кількісний аналіз ГФКБ проводили шляхом порівняння інтенсивності забарвлення відповідних поліпептидних зон, що були віднесені до кількості загального білка у фракції. Загальний білок визначали методом Лоурі в модифікації Міллера (Miller, 1959). Рівень перекисного окиснення ліпідів (ПОЛ) вимірювали з використанням тест-набору LPO-586 (Oxis Int. Inc., USA) (Ohkawa et al., 1979). Обробку отриманих даних проводили методами математичної статистики з використанням програми Statistica 6. Відносний вміст ГФКБ і продуктів ПОЛ виражали у вигляді середньої величини \pm стандартна похибка середньої. Достовірну відмінність між групами оцінювали із застосуванням $t$-критерію Стьюдента $(P<0,01)$ після перевірки гіпотез про нормальність розподілу та відмінність між генеральними дисперсіями.

\section{Результати та їх обговорення}

Анатомоморфологічне дослідження риб у всіх групах не виявило відхилення від нормального розвитку, аберації та потворності. Результати кількісної оцінки вмісту білка гліальних проміжних філаментів у мозку риб показали значні відмінності досліджених груп (рис. 1). У мозку бичка-пісочника, виловленого у прибережних водах бухти Керченська, виявлено достовірне зростання ГФКБ (в 2,28 раза, $P<0,001)$ порівняно з групою риб з умовно чистої ділянки (р. Ворскла). Отриманий результат вказує на розвиток гліальної реактивації в результаті метаболічних порушень, викликаних підвищеним вмістом токсинів у придонних біотопах бухти Керченської. Цей показник був також вищим за відповідний у мозку риб із р. Самара, що вказує на значний несприятливий вплив забруднювачів у бухті Керченській.

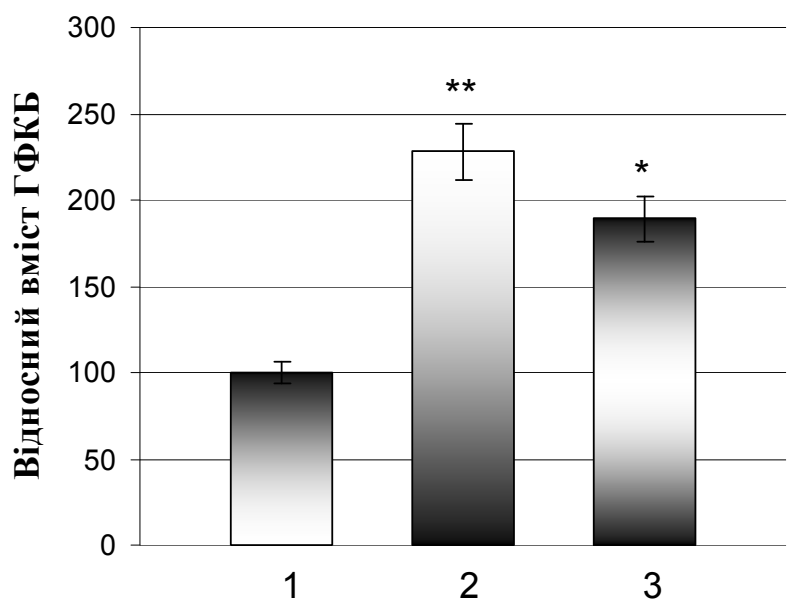

Рис. 1. Відносний вміст ГФКБ у мозку бичка-пісочника бухти Керченської (2) порівняно 3 контрольною ділянкою р. Ворскла (1) і ділянкою p. Самара (3): * $-P<0,01,{ }^{* *}-P<0,001$ відносно 1

Підвищення вмісту білка гліальних філаментів - це наслідок збільшення числа субпополяції окремих гліоцитів, у першу чергу за рахунок диференціації гліальних попередників у зрілі астроцити. Реактивація астроцитів отримала назву «астрогліоз». Астрогліоз індукується різними за природою чинниками та є ознакою патогенетичних і структурних ушкоджень ЦНС. Участь астроцитів у репарації ушкоджень ЦНС широко вивчається останнім часом. Зміни, якими супроводжується астрогліоз, спрямовані від оборотних 
змін експресії генів і клітинної гіпертрофії до тривалого формування рубців і перебудови структури окремих ділянок мозку (Sofroniew and Vinters, 2010).

Результати визначення поліпептидного складу ГФКБ у мозку риб, що мешкають у прибережних зонах бухти Керченська і річки Самара Дніпровська, показали значне зростання кількості деградованих поліпептидів ГФКБ (рис. 2). Найзначніші зміни ГФКБ виявлені в цитоскелетних фракціях білків.

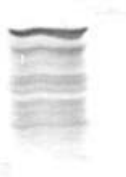

B
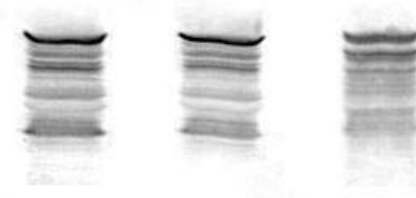

K

K

C

Рис. 2. Результати імуноблотингу цитоскелетних фракцій білків із мозку

бичка-пісочника р. Ворскла (B), бухти Керченської $(K)$ і ділянки р. Самара $(C)$

Вміст кінцевих продуктів перекисного окиснення ліпідів (ПОЛ) у тканині мозку групи риб, виловлених у вищезгаданих ділянках, свідчить про передумови розвитку окисного стресу (рис. 3). Зміни показників окисного стресу та астрогліозу в мозку бичка-пісочника бухти Керченська, p. Самара та р. Ворскла мали високий коефіцієнт кореляції $(r=0,69 \pm 0,091$ і $r=0,74 \pm 0,087$ відповідно).

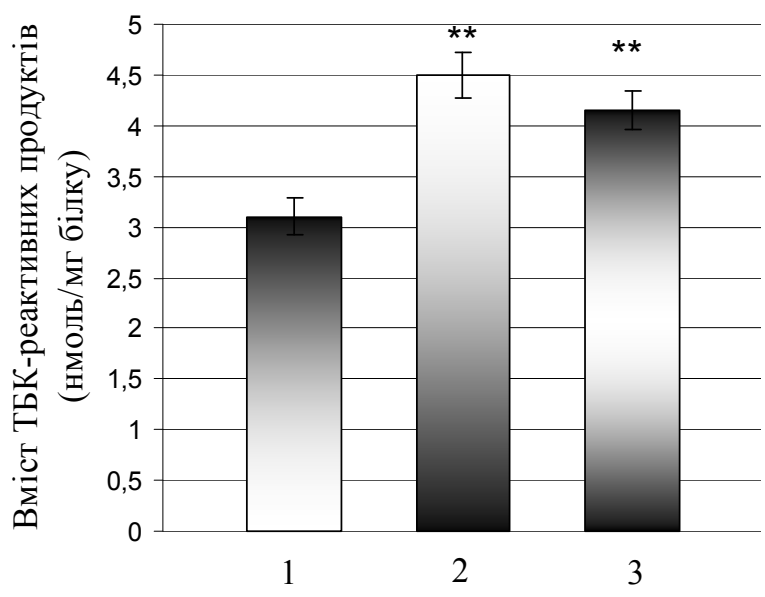

Рис. 3. Вміст кінцевих продуктів перекисного окиснення ліпідів у мозку бичка-пісочника

р. Ворскла (1), бухти Керченської (2) та р. Самара (3): * $-P<0,05, * *-P<0,01$ відносно групи 1

Таким чином, вивчення відповідних реакцій популяцій донних риб є актуальним завданням в оцінці дії різних несприятливих чинників, у тому числі десорбції нафтопродуктів із донних відкладів. Риби зручні об'єкти в екологічних дослідженнях через високу чисельність, поширення та доступність для вивчення реакції організмів на дію полютантів (Bucher et al., 1992).

Використання як біомаркерів гістоспецифичних цитоскелетних білків, які виконують життєво необхідні функції нервової системи та надзвичайно чутливі до дії несприятливих чинників, - найперспективніший напрям (Kalman and Pritz, 2001; Nedzvetskii et al., 2006). Як і в інших хребетних, у риб нейроглія відіграє життєво важливу роль у підтримці та забезпеченні функціонування нейронів. Нейрогліальні клітини особливо критичні для підтримання гомеостазу мозку, репарації ушкоджень, захисту нейронів від різних дій. Несприятливі дії різної природи індукують характерну клітинну відповідь глії астрогліоз. Астрогліоз, тобто реактивация астроцитів, завжди супроводжується активацією фібрилогенезу та синтезу ГФКБ (Nedzvetskiy and Nerush, 2011). Надмірно інтенсивний фібрилогенез $є$ головним показником реактивної відповіді астроцитів на нейрональні ушкодження. Перебудова проміжних філаментів астроглії може бути необхідною умовою для адекватного функціонування гліальних клітин за дії ушкоджувальних чинників (Norton et al., 1992).

Виявлене нами достовірне підвищення експресії білка гліальних проміжних філаментів свідчить про індукований астрогліоз, тобто функціональну відповідь нейроглії на дію несприятливих факторів. Характерне збільшення кількості деградованих поліпептидних фрагментів ГФКБ є ознакою цитоскелетних перебудов, порушення стану цитоскелета, морфології та функціонування клітин нервової тканини. Отже, стан гліального цитоскелета може бути валідним показником токсичної дії нафтового забруднення морських вод.

Окисний стрес - найпоширеніше метаболічне порушення за дії несприятливих чинників (Baydas et al., 2004). Проміжні високореактивні продукти окисного стресу є важливою причиною нейродегенерації та зниження життєздатності в умовах дії токсичних забруднювачів різної природи. Дія промислових забруднювачів на організм викликає порушення енергетичного метаболізму у клітинах, морфологічні та структурні аномалії.

Виявлена у цьому дослідженні позитивна кореляція показників астрогліозу, тобто стану цитоскелета нейроглії, та окисного стресу в мозку бичка-пісочника 3 промислово забруднених і умовно чистих ділянок водойм указує на те, що окислювальні ушкодження можуть бути одним з основних механізмів реалізації токсичних ефектів забруднювачів. Порушення на молекулярному рівні лежить в основі патологічних процесів та відбиваються на наступних, вищих рівнях біологічної організації, у тому числі на структурно-функціональній організації екосистем.

Отриманий результат про реактивний астрогліоз у мозку риб, що мешкають у забруднененому середовищі Керченської протоки, вказує на певний рівень адаптації клітин нервової системи до несприятливих умов, викликаних забрудненням.

\section{Висновки}

Вивчення впливу забруднювальних речовин на гідросистему не може бути обмежене проведенням дослідів лише на організменому рівні, оскільки дозволяє виявити аномальні зміни лише на пізніх стадіях інтоксикації, коли організм перебуватиме на межі 
загибелі. Отримані результати переконливо свідчать, що виявлені цитоскелетні перебудови в мозку риб виникли під впливом несприятливих антропогенних чинників навколишнього середовища. Це дає змогу розглядати ГФКБ як надійний i достовірний маркер токсичного впливу полютантів, за допомогою якого можливо оцінити ушкоджувальні ефекти на ранніх етапах і розробити ефективні заходи компенсації патогенетичних порушень.

Отримані дані про порушення метаболізму специфічного білка цитоскелета нейроглії бичкапісочника з бухти Керченська свідчать про негативний вплив нафтопродуктів на донні біотопи Керченської протоки та гідробіонтів, які населяють їх. Наведені результати вказують на необхідність постійного екологічного моніторингу та комплексного дослідження донних біотопів цього регіону.

\section{Бібліографічні посилання}

Baydas, G., Donder, E., Kiliboz, M., Nedezvetsky, V., 2004 Neuroprotection by $\alpha$-lipoic acid in streptozotocin-induced diabetes. Biochem. (Mosc.) 69(9), 1001-1005.
Bucher, F., Hofer, R., Salvenmoser, W., 1992. Effects of treated paper mill effluents on hepatic morphology in male bullhead (Cottus gobio L.). Arch. Environ. Contam. Toxicol. 23, 410-419.

Kalman, M., Pritz, M., 2001. Glial fibrillary acidic protein immunopositive structures in the brain of a crocodilian, Caiman crocodilus, and its bearing on the evolution of astroglia. J. Comp. Neurol. 17, 460-480.

Miller, G.L., 1959. Protein determination for large numbers of samples. Anal. Chem. 31(5), 964-966.

Nedzvetskii, V.S., Tuzcu, V., Yasar, A., Tikhomirov, A.A., 2006. Effects of vitamin E against aluminum neurotoxisity in rats. Biochem. (Mosc.) 71(3), 239-244.

Nedzvetskiy, V.S., Nerush, P.A., 2011. Hyperthyreosis effects on the learning, memory and glial intermediate filaments of a rat brain. Int. J. Physiol. Pathophysiol. 2(3), 269-278.

Norton, W.T., Aquino, D.A., Hozumi, I., 1992. Quantitative aspects of reactive gliosis: A review. Neurochem. Res. 17(9), 877-885.

Ohkawa, H., Ohishi, H., Yagi, K., 1979. Assay for lipid peroxides in animal tissues by thiobarbituric acid reaction. Anal. Biochem. 95(2), 351-358.

Sofroniew, M.V., Vinters, H.V., 2010. Astrocytes: Biology and pathology. Acta Neuropathol. 119, 7-35.

Надійшла до редколегї 24.03.2014 